\title{
Reinventing Saint Francis: Józef Wittlin, Anti-Semitism and the Idea of Modern Sainthood
}

\author{
Święty Franciszek ponownie odkryty: Józef Wittlin, antysemityzm i idea \\ nowoczesnej świętości
}

\begin{abstract}
This article discusses Józef Wittlin's literary exploration of the idea of modern sainthood. It argues that Wittlin's search for a new model of saintly life that would respond to the modern age was informed by the ongoing theological debates about the meaning and value of traditional hagiography. The article demonstrates that Wittlin's reflections were inspired by Paul Sabatier's influential study Vie de saint François d'Assise (Life of Saint Francis of Assisi), and informed by the immediate socio-political context (the Polish-Ukrainian War of 1918-1919 and the rise of anti-Semitism in Europe). Ultimately, Wittlin's writings reinvent Saint Francis as a modern-day saint who shows a radical empathy with the persecuted and the marginalised, above all the Jews. Responding to growing anti-Semitism that was endorsed by a number of nationalist and Roman Catholic groups, Wittlin reimagines Saint Francis as a social activist who gives active attention to the suffering of the vilified "other" who has been rejected by mainstream society.
\end{abstract}

Keywords: Józef Wittlin, Paul Sabatier, hagiography, sainthood, St Francis, anti-Semitism, modernist theology

Streszczenie: Artykuł omawia literacką konstrukcję ideału współczesnej świętości w twórczości Józefa Wittlina. Artykuł dowodzi, że Wittlinowskie poszukiwanie nowego modelu świętości, która mogłaby odpowiedzieć na wyzwania epoki nowoczesności, wpisuje się w dwudziestowieczne spory teologiczne dotyczące znaczenia i wartości tradycyjnie pojmowanej hagiografii. Artykuł pokazuje, że refleksje Wittlina były inspirowane wpływową pracą Paula Sabatiera Vie de saint François d'Assise (Życie świętego Franciszka z Asyżu) oraz związane z bezpośrednim kontekstem społeczno-politycznym (wojną polsko-ukraińską oraz rosnącym antysemityzmem). W swojej twórczości Wittlin przedstawia świętego Franciszka jako świętego na miarę epoki nowoczesnej, który wykazuje się radykalną empatią w stosunku do ludzi prześladowanych i marginalizowanych, przede wszystkim Żydów. Reagując na nasilający się antysemityzm, który znajdował uznanie w środowiskach narodowych i katolickich, Wittlin ukazuje świętego Franciszka jako działacza społecznego skupiającego się na cierpieniu tych, którzy są odrzucani przez społeczeństwo jako godni pogardy i naznaczeni „innością”. Słowa kluczowe: Józef Wittlin, Paul Sabatier, hagiografia, świętość, Św. Franciszek, antysemityzm, teologia modernistyczna 
Józef Wittlin's writings show a sustained interest in the idea of modern sainthood, which he explores against the backdrop of contemporary theological debates and socio-political developments. In his essays, poetry, and diaries, Wittlin considered ways in which the Christian ideal of sainthood could be achieved in the century that had been scarred by growing political unrest, mass violence, technologically advanced warfare, and widespread anti-Semitism leading to the genocide of millions of European Jews. Could the ideal of saintly life be sustained in such conditions? Might the medieval narratives of miraculous conversions still have any practical significance in the twentieth century? Would it be possible to rewrite or reinvent them so as to make them gain new social and political relevance? These questions, central to Wittlin's literary and personal reflections, were also at the heart of the ongoing theological debates raging across Europe since the late nineteenth century.

\section{Modernist Hagiography: Rewriting the Lives of Saints for the $20^{\text {th }}$ Century}

Józef Wittlin's reconceptualisation of the medieval genre of hagiography ought to be read in the context of contemporary theological disputes about the manner in which modernity requires a radical revision of traditional saints' lives narratives. In 1905, the Belgian Jesuit Hippolyte Delehaye proposed to adopt a more critical attitude towards "the vague sentiment which endows hagiographers with some mysterious privilege of immunity from the errors of human frailty to which all other categories of writers are liable." As it soon turned out, his study Les Légendes hagiographiques (The Legends of the Saints), together with works by other members of the Bollandist society that brought together Jesuit historians and philologists studying lives of saints and martyrs, became a major landmark in the history of hagiography. The Bollandists' objective was to establish new critical editions of hagiographies based on extensive historical research and newly available archival material. Inspired by a new approach to historiography, they "aimed at transcending a binary mentality (...) which equated myth or legend with falsity and history with factual truth." ${ }^{2}$ They proposed to revise traditional

1 H. Delehaye, The Legends of the Saints: An Introduction to Hagiography, trans. V.M. Crawford, London: Longmans, Green, and Co., 1907, p. ix. Originally published as Les Légendes hagiographiques, Brussels: Société des Bollandistes, 1905.

2 C.J.T. Talar, "Discourse on Method: Hippolyte Delehaye’s Légendes hagiographiques" [in:] Medieval Saints in Late Nineteenth Century French Culture: Eight Essays, ed. E. Emery, L. Postlewate, Jefferson, NC: McFarland \& Co., 2004, pp. 139-160 (p. 145). For a more extensive discussion of the Bollandists' work, see Hippolyte Delehaye, Work of the Bollandists through 
accounts of saints' lives in the light of the existing documents and contemporary socio-historical research, so as to provide a solid scholarly counter-balance to the sentimental legends of the miraculous and supernatural that, over the centuries, had come to surround most Christian saints.

One of the first studies that set the precedent for such a revisionist approach and won great popularity among scholars and lay readers alike was Paul Sabatier's Vie de saint François d'Assise (Life of Saint Francis of Assisi). Published in 1893, it was soon translated into English and German. ${ }^{3}$ Sabatier was a Calvinist pastor with a keen interest in the theological movement of modernism and an ardent advocate of the critical historical method. ${ }^{4} \mathrm{His}$ account of Francis's life is preceded by a critical discussion of the primary and secondary material available, as well as an exposition of Sabatier's views of the nature of historiography. He strongly advocates a hermeneutic approach to history, drawing attention to the subjective dimension of history-writing. He emphasises that there is no objective and universally accessible past since historical interpretation is always necessarily subjective:

History is a landscape, and like those of nature it is continually changing. Two persons who look at it at the same time do not find in it the same charm, and you yourself, if you had it continually before your eyes, would never see it twice alike. (...) It is the same with the landscapes of history. Narrow minds cannot accommodate themselves to these perpetual transformations: they want an objective history in which the author will study the people as a chemist studies a body. It is very possible that there may be laws for historic evolution and social transformations as exact as those of chemical combinations, and we must hope that in the end they will be discovered; but for the present there is no purely objective truth of history. ${ }^{5}$

Three Centuries, 1615-1915, Princeton: Princeton University Press, 1922; A. Gwynn, "The Bollandists: Past and Present," Studies: An Irish Quarterly Review 1946, vol. 35, no. 137, pp. 53-62.

3 P. Sabatier, Vie de saint François d'Assise, Paris: Libraire Fischbacher, 1893; published in English as Life of St. Francis of Assisi, trans. L.S. Houghton, London: Hodder and Stoughton, 1894; in German as Das Leben des heiligen Franz von Assisi, trans. M. Lisco, Berlin: De Gruyter, 1895. All quotations are from the English translation. On the theological impact of Sabatier's study, see C.J.T. Talar, "Saint of Authority and the Saint of the Spirit: P. Sabatier's Vie de saint François d'Assise" [in:] Sanctity and Secularity during the Modernist Period: Six Perspectives on Hagiography Around 1900, ed. L.F. Barmann, C.J.T. Talar, Brussels: Société des Bollandistes, 1999, pp. 131-150.

${ }^{4}$ For comprehensive accounts of the development of the modernist controversy in the Roman Catholic Church, see Catholicism Contending with Modernity: Roman Catholic Modernism and Anti-Modernism in Historical Context, ed. D. Jodock, Cambridge: Cambridge University Press, 2000; D.G. Schultenover, A View from Rome: On the Eve of the Modernist Crisis, New York: Fordham University Press, 1993; U.S. Catholic Historian, 2007, 25(1): Pascendi dominici gregis 1907-2007: Centennial Essays on Responses to the Encyclical on Modernism.

5 P. Sabatier, Life of St. Francis of Assisi, op. cit., p. xxxi. 
Since, according to Sabatier, an objective view of history is a "utopia," he urges a critical examination of saints' biographies, accusing official Church historians of adorning their narratives with superfluous "embellishments" and portraying saints as "superhuman creatures, having nothing in common with us:"6

they are privileged characters, marked with the divine seal; they are, as the litanies say, vials of election, into which God has poured the sweetest perfumes; their sanctity is revealed almost in spite of themselves; they are born saints as others are born kings or slaves, their life is set out against the golden background of a triptych, and not against the sombre background of reality. By such means the saints, perhaps, gain something in the respect of the superstitious; but their lives lose something of virtue and of communicable strength. Forgetting that they were men like ourselves, we no longer bear in our conscience the command, "Go and do likewise."”

Both Sabatier and Delehaye, in their attempts to reform and modernise hagiography, seek to recover the "communicable strength" of saints' lives, and present them in a way that would make them both convincing and inspiring for the modern reader. This meant finding a balance between the otherworldliness of saints and their humanity. Sabatier's and Delehaye's approach was met with considerable criticism from the Vatican. Sabatier's book was placed on the Index, whereas Delehaye was asked to revise parts of his work. It was feared that a critical examination of saints' lives that undermines the truth value of a number of miraculous stories and legends might soon foster a similar approach to reading and interpreting the Scripture. ${ }^{8}$ Nevertheless, their studies got translated into a number of languages and, in Sabatier's case, gained instant popularity and scholarly appreciation within the French Academy. ${ }^{9}$

6 Ibidem, pp. xxxiii-xxxiv.

7 Ibidem, p. xxxiv.

8 See E. van der Wall, The Enemy Within: Religion, Science, and Modernism, Wassenaar: NIAS, 2007, pp. 31-32.

9 Between 1894 and 1910, Vie de saint François d'Assise ran to thirty-nine editions in France alone. It greatly contributed to reviving interest in Francis of Assisi across Europe, and a number of studies of his life and Franciscan spirituality followed. In 1902, Sabatier founded the International Society for Franciscan Studies, which aimed to promote research on Franciscan spirituality and publish primary and secondary sources on the history of the Franciscan order. See also B. Williams, The Franciscan Revival in the Anglican Communion, London: Darton, Longman and Todd, 1982; A. Vauchez, Francis of Assisi: The Life and Afterlife of a Medieval Saint, trans. M.F. Cusato, New Haven: Yale University Press, 2012, pp. 324-336. 


\section{Religion and Conflict in Józef Wittlin’s Writings}

Wittlin became familiar with Sabatier's work in the early 1920s, when he developed an interest in Saint Francis and began researching his life in preparation for writing his own biography of Francis (which he never completed). ${ }^{10}$ Sabatier's study had a much more profound influence on Wittlin than other biographies of Saint Francis that he studied. It inspired his reflections on the idea of modern sainthood, which became central to a number of his poems and prose texts. Similarly to Sabatier, Wittlin ascertained the necessity to revise the traditional ideal of sainthood, which he considered too disengaged from the contemporary world. Francis features prominently in Wittlin's poetry. Wittlin views his person as a model for socially engaged Christianity that reaches out to those who are humiliated and abused. In the 1930s, when anti-Semitism began to hold sway over Europe's political discourse and was embraced by a number of prominent Christian intellectuals and priests, Wittlin voiced his protest in the poem "Święty Franciszek i biedni Żydzi" (Saint Francis and the Poor Jews). Ten years later, he himself was forced to flee Europe to save his life.

Several scholars who discussed Wittlin's work have noted that religious imagery and symbolism play an important role in his poetry and prose. ${ }^{11}$ However, apart from passing remarks, there has not been much critical discussion of Wittlin's use of religious themes and motifs. Only recently has Ryszard Zajączkowski concluded that issues related to religion were of primary concern for Wittlin, and were constantly present in his private reflections. ${ }^{12}$ As Zajączkowski has pointed out, the full content of Wittlin's unpublished notebooks and personal journals has never been properly explored, and still awaits a thorough critical examination. ${ }^{13}$ The fact that Wittlin's reflections

10 The titles that Wittlin read in the 1920s-1930s included the 1923 edition of Sabatier's Vie de saint François d'Assise; R. Saitschick, Franziskus von Assisi, München: C.H. Beck, 1917; U. Peters, Franz von Assisi, Tübingen: Mohr, 1912; G. Faure, Pèlerinages d'Italie: au pays de Saint François d'Assise et de Sainte Catherine de Sienne, Paris: Perrin, 1920; G.K. Chesterton, Saint Francis of Assisi, London: Hodder and Stoughton, 1923; Thomas of Celano, The Life of Saint Francis; J. Wittlin, [Diaries], I: 1920s-1932 [1920s, pp. 106, 113].

11 See Z. Yurieff [in:] Joseph Wittlin, New York: Twayne Publishers, 1973; R. Cudak, “'Otom przed Tobą, Abraham’: Lektura wiersza Józefa Wittlina 'Trwoga przed śmiercią"” ["I, Abraham, Stand before You”: A Reading of the Poem "Fear of Death" by Józef Wittlin] [in:] Studia o twórczości Józefa Wittlina [Studies on the Writings of Józef Wittlin], ed. I. Opacki, Katowice: Uniwersytet Śląski, 1990, pp. 34-54; E. Kosakowska, "The War as a Myth: The Analysis of a Development of the Religious Imagery in Joseph Wittlin's The Salt of the Earth" [in:] Between Lvov, New York, and Ulysses' Ithaca: Józef Wittlin: Poet, Essayist, Novelist, ed. A. Frajlich, Toruń: Nicholas Copernicus University, 2001, pp. 61-72.

12 R. Zajączkowski, "Wolne usta poety: Ethos słowa Józefa Wittlina" [The Poet's Free Lips: Józef Wittlin’s Verbal Ethics], Ethos [Ethos] 2012, 97-98, pp. 261-278.

13 The journals and notebooks are part of the Józef Wittlin Collection of the Museum of Literature in Warsaw, MS 934-970. They reveal a wealth of information about the works 
on religion in general, and Christianity in particular, are recorded primarily in his unpublished manuscripts is very much connected to the socio-political context in which his interest in Christianity developed.

Brought up in a Jewish family, Wittlin became drawn to Christianity as an adult. His first volume of poetry, published in 1920, contains a number of Christian images and themes. By the mid-1930s, reflections on religious topics became extremely frequent in his personal journal, and he even considered getting baptised. However, he came to the conclusion that, in the face of growing anti-Semitism and violent persecutions of Jews, he could not take such a step. "At this time of contempt and hatred," he recorded in his journal, "I have the honour to belong to those who are despised and hated." "Getting baptised under such circumstances," he continued, "would be a sin against the Holy Spirit." 15 Thus, while in his private journal he began referring to himself as a Christian, he did not officially renounce Judaism and did not attend any Christian services. A few years later, Wittlin paid tribute to Henri Bergson (whose father, Michał Bergson, was a Warsaw-born Polish Jew) when he learnt that Bergson shared Wittlin's conviction that in the face of Nazism the ultimate act of Christian faith was, paradoxically, not to renounce one's Jewish roots. ${ }^{16}$ Similarly to Bergson, Wittlin took a personal vow to remain with Jews as long as they were persecuted. He kept his word, and became baptised into the Roman Catholic Church only in 1953.

It is worth noting that Wittlin did not perceive the act of baptism as the climax of his spiritual journey, but as its beginning. "I did not enter a safe, sheltered harbour, where my boat or ship will be anchored," he wrote in his journal just after his baptism, "On the contrary: now I must face the storm. On 23 May 1953 I just hung up a flag under which I am going to sail." ${ }^{17}$ Furthermore, he did not regard his baptism as a break from the Judaic tradition in which

that Wittlin read, include quotations from the texts he found inspiring (often accompanied by his own commentaries), and contain a number of drafts of his poems and prose pieces. Since they have not been assigned a classmark yet, I refer to them as [Diaries] and provide dates for quoted entries.

14 J. Wittlin, [Diaries], 12 vols, v: 1935-1937 [1937, p. 515].

15 Ibidem. A sin against the Holy Spirit, according to the Gospel of Mark, is the only sin that would not be forgiven. See Mark 3, 28-29.

16 In his last will, dated 8 February 1937, Bergson wrote: "My reflections have led me closer and closer to Catholicism, in which I see the complete fulfilment of Judaism. I should have become a convert, had I not seen in preparation for years (...) the formidable wave of antisemitism which is to sweep over the world. I wanted to remain among those who tomorrow will be persecuted." In 1940, when French Jews were required to register with the Nazi authorities, Bergson, in recognition of his achievements, was granted the status of an "Honorary Aryan." He rejected it, and chose to register with other Jews. See N. Sokolow, "Henri Bergson's Old-Warsaw Lineage" [in:] L.S. Dawidowicz, The Golden Tradition: Jewish Life and Thought in Eastern Europe, Syracuse, NY: Syracuse University Press, 1996, pp. 349-359 (pp. 349-350).

17 Quoted in R. Zajączkowski, op. cit., p. 271. 
he was raised. He saw continuity between his ancestral faith and the newly acquired Christianity. "I am a Christian," he wrote in his journal in 1940, "because I am a Jew. My Jewishness helps me greatly to understand Christ. (...) I simply cannot see any problem with it. For me, the New Testament is divided from the Old Testament by only one empty page." 18

Searching for a viable ideological position, Wittlin first turned to pacifism, and tried to conceive of war as an act of violence imposed on peacefully-minded people by their distant and politically-blind governing bodies. However, he soon distanced himself from what he considered to be pacifism's naivety. He could no longer embrace it after the experience of the Polish-Ukrainian War of 1918-1919, which found him in Lwów, at the very centre of the fighting. ${ }^{19}$ The violence taking place in the streets of Lwów, he later wrote, was accompanied by "battles (...) raging in [his] conscience." ${ }^{20}$ His loyalties were divided, and he could not find a way to reconcile them. As he later recounted in his essay "Ze wspomnień byłego pacyfisty" (Confessions of an Ex-Pacifist), it was poetry that helped him survive this difficult period:

In those memorable days of November 1918, like all the people of Lwów, we had to face a categorical question: should Lwów be Polish or Ukrainian? There was no third alternative, and you could already hear shots in the streets. My late friend Jan Stur and I - both pacifists - replied without hesitation: Polish. So we should have supported the war that was already taking place. We did not. Our sentimental patriotism was in too serious conflict with our pacifism. We should have established a hierarchy of values. It did not work out. There was an absolute balance in our conflicted feelings: we could neither resign from our attachment to Polish Lwów for the sake of our pacifism, nor subordinate our pacifism to our Polish identity. In the end we fell victim to a tragic dissonance, the only escape from which was poetry. As for me, I could not accept either reality. (...) After several months of heavy fighting, only poetry could save me from despair. (...) How idyllic in its simplicity seemed to me then the monstrous world war, during which I could keep my conscience pure and take a firm stance. The Polish-Ukrainian War and the Jewish pogrom in Lwów, in contrast, forced on me tragic dilemmas that I could not resolve either in my conscience or in my reason. ${ }^{21}$

18 J. Wittlin, [Diaries], vi: 1938-1940 [January 1940, pp. 368-369].

19 On the Polish-Ukrainian War and the Jewish pogrom in Lwów, see W.W. Hagen, “The Moral Economy of Popular Violence: The Pogrom in Lwów, November 1918” [in:] Antisemitism and Its Opponents in Modern Poland, ed. R. Blobaum, Ithaca, NY: Cornell University Press, 2005, pp. 124-147.

20 J. Wittlin, "Ze wspomnień byłego pacyfisty" [Confessions of an Ex-Pacifist] [in:] Orfeusz $w$ piekle XX wieku [Orpheus in the Inferno of the Twentieth Century], Kraków: Wydawnictwo Literackie, 2000, pp. 73-91 (p. 77) (first publ. in Wiadomości Literackie [Literary News], 5 January 1930 , pp. 1-2).

21 Ibidem, pp. 77-78. 
In his further reflections on World War I, Wittlin expressed his disappointment with the role Christian churches played in the conflict. ${ }^{22}$ In his view, the fact that during the war religions sided with different armies, priests accepted military titles, and religious language was ever-present in the discourse of political propaganda put Christianity to shame. ${ }^{23} \mathrm{He}$ argued that the alliance of religion and politics was flawed from the beginning because while people were busy "rendering unto Caesar what belonged to Caesar, what belonged to God was not rendered unto God." 24

\section{Reinventing Sainthood in the Age of Violence}

Wittlin's disillusionment with the role that institutional religion played in the war led him to a search for a new, radical model of Christian sainthood. A model that would be capable of entering into a dialogue with modernity, and whose nature would render it impossible to use instrumentally as a propaganda tool. In the aftermath of World War I, Wittlin became increasingly attracted to Franciscan spirituality, and briefly considered entering the Franciscan Order. ${ }^{25}$ Throughout the 1920s he continued to study different biographies of Francis of Assisi, including Sabatier's work. Twice, in 1925 and 1926, he travelled to Assisi, which he came to call a terra mystica. ${ }^{26}$ His fascination with the Franciscan vision of life was so intense that it was occasionally mocked by his contemporaries, as illustrated by Władysław Daszewski's caricature (see Figure 1), presenting Wittlin as an inspired sage dressed in a Franciscan robe. Eventually, on his baptism in 1953, Wittlin took the names of Franciszek Maria (Francis Mary). ${ }^{27}$ Wittlin's interest in Francis of Assisi was not accidental. The early twentieth century saw a great

22 For a discussion of how different religious denominations were implicated in the war, see Ph. Jenkins, The Great and Holy War: How World War I Became a Religious Crusade, New York: HarperOne, 2014.

23 J. Wittlin, "Wojna, pokój i dusza poety" [War, Peace, and the Poet's Soul] [in:] Orfeusz w piekle XX wieku [Orpheus in the Inferno of the Twentieth Century], pp. 16-44 (pp. 19-21).

24 Ibidem, p. 20.

25 In a 1921 letter to the literary critic and translator Kazimiera Żuławska, Wittlin wrote: "I'm thinking whether, after I finish translating the Odyssey and writing a couple of shorter pieces, I ought to get baptised and enter the Franciscan Order. (...) I feel I could make a real change in the world, not by means of books, but a living word." "Letter to Kazimiera Żuławska, 1 May 1921" [in:] J. Wittlin, Listy [Letters], ed. T. Januszewski, Warszawa: Niezależna Oficyna Wydawnicza, 1996, pp. 22-23.

26 Wittlin published his travel narratives interspersed with spiritual reflections as a series of essays that first came out in different literary magazines in 1926-1927, and were later collected in Orfeusz w piekle XX wieku [Orpheus in the Inferno of the Twentieth Century], pp. 173-191.

27 J. Wittlin, "Letter to Roman Brandstaetter, 30 December 1959," quoted in R. Zajączkowski, "Korespondencja między Józefem Wittlinem i Romanem Brandstaetterem" [Correspondence between Józef Wittlin and Roman Brandstaetter], Tematy i Konteksty [Subjects and Contexts] 2012, 2 (7), pp. 151-173 (p. 160). 
revival of Franciscan spirituality, which reached its climax in the events and publications that commemorated the seventh centenary of Francis's death in $1926 .{ }^{28}$ The wide appeal that Francis enjoyed in the period can be attributed partly to the way in which he was portrayed in a number of contemporary hagiographies - as an inspired outcast, a social reformer, and a severe critic of institutionalised religion, and partly to the discovery of new archival material on which some of these works were based. ${ }^{29}$

In the introduction to the biography of Francis that Wittlin began writing in the mid-1920s, similarly to Sabatier, he vows to "take off the burning halo' from Francis's head, stating: "its glow blinds me and prevents me from looking directly into the face that I wish to portray." ${ }^{30} \mathrm{He}$ asserts that his

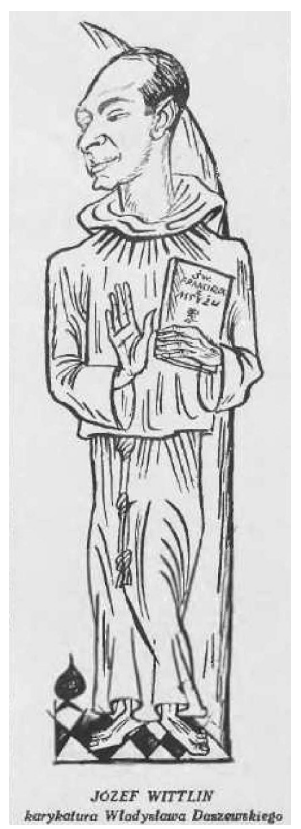

Figure 1. Józef Wittlin as Saint Francis of Assisi. A drawing by Władysław Daszewski accompanying a review of the second edition of Wittlin's volume Hymny [Hymns]. Wiadomości Literackie [Literary News], 8 January 1928, p. 3.

28 On the 1926 commemorations of Francis, see A.G. Little, "The Seventh Centenary of St. Francis of Assisi (1226-1926)" [in:] Franciscan Essays II, ed. F.C. Burkitt, H.E. Goad, A.G. Little, Manchester: University Press, 1932, pp. 1-17.

29 The most important contemporary discovery was the manuscript of Speculum Perfectionis (The Mirror of Perfection) allegedly written by Brother Leo. It was published by Sabatier in 1898, and soon became the subject of heated debates. Sabatier claimed that it belonged to the oldest existing documents providing insight into Francis's life and teaching, since it was dated 1227-1228. However, other scholars undermined his stance, proving that the copyist must have made a mistake, and the documents were most probably not older than 1318 .

30 Wittlin published the introduction and first four chapters of his book, which he called a "literary monograph," in the journals and magazines Skamander [Scamander] 1927, 7 (49), 
biography is not meant to be a book about "a hero who passed away," adding that when he looks into Francis's face, his eyes reflect the "living substance of the world." ${ }^{11}$ In his narrative, Wittlin follows in the steps of Sabatier, focusing less on the miraculous events in Francis's life and more on the contemporary relevance of his teaching. One of the aspects of Francis's life that he particularly emphasises is his experience of warfare. In 1202, when Francis was twenty years old - just like Wittlin when he volunteered for the Austro-Hungarian Army - he took part in the war between Assisi and Perugia. The final scene of the battle, as depicted by Wittlin, becomes the beginning of Francis's in-depth reflection on faith and, eventually, his conversion:

Francis can hear the wail of the wounded, he can smell the odour of chopped flesh. He is exhausted. The sun sets.

'God is with us!' yells Assisi.

'God is with us!' yells Perugia.

'Actually, with whom is God?' thinks Francis. He turns his head and tries to spot God. But he can only see people, living and dead. Living and dead horses.

At this moment, he was taken hostage. ${ }^{32}$

In Wittlin's narrative, the harrowing experience of the war makes Francis suspicious of a totalising approach to God and military rhetoric that uses religion for propaganda purposes. Though Wittlin never finished his biography of Francis - its manuscript burnt in the Nazi invasion of Warsaw during World War II - the image of the saint that emerges from the chapters that he completed is that of a man who, in Wittlin's words, can be regarded both as "great social reformer" and "an inspired poet." ${ }^{33} \mathrm{He}$ is fascinated with troubadour poetry, sensitive to social injustice, and eager to work towards alleviating the suffering of those who are marginalised and rejected by society. Such a rendering of Francis's life, can well be read as Wittlin's response to the bleak post-war life. By the mid-1920s, he became increasingly disillusioned with the political and ideological landscape of post-war Europe. The newly acquired Polish independence did not translate into a peaceful vision of the future with which, as he reminisces, soldiers were fed during the war. As Norman Davies

pp. 19-35; Gtos Prawdy [The Voice of Truth] 1927, 105; Prady [Currents] 1931, 2, pp. 42-46; Tygodnik Ilustrowany [Illustrated Weekly] 1932, 25-28; Kultura [Culture] 1932, 7. They were subsequently reprinted as "Święty Franciszek z Asyżu" [Saint Francis of Assisi] [in:] J. Wittlin, Pisma pośmiertne i inne eseje [Posthumous Writings and Other Essays], ed. J. Zieliński, Warszawa: Biblioteka Więzi, 1991, pp. 55-101; J. Wittlin, Święty Franciszek z Asyżu [Saint Francis of Assisi], Warszawa: Biblioteka Więzi, 1997. All subsequent quotations are from Pisma posmiertne $i$ inne eseje. The sentence quoted is from page 55.

31 Ibidem, p. 55.

32 Ibidem, p. 84.

33 Ibidem, pp. 57-58. 
observes, the "rebirth of Poland seemed to many Jews to herald the crossing of Jordan (...) an end of the chronic insecurity which had prevailed for almost half a century." ${ }^{34}$ However, the reality proved to be much more disheartening.

Wittlin's poetry of the 1920s-1940s is very much informed by its immediate historico-political context. During the inter-war period, the former peaceful borderland provinces turned into areas replete with nationalist tensions. One of the four major parties on the Polish political scene, the right-wing Narodowa Demokracja (National Democracy) led by Roman Dmowski, was set on turning the newly independent country from a multi-ethnic state (in the inter-war period one third of Poland's population consisted of Ukrainian, Belarussian, Jewish, and German minorities) into an ethnically-, linguistically-, and religiously-homogenous nation-state. ${ }^{35}$ As the Great Depression of the 1930s set in, nationalism and anti-Semitism began to rise. Wittlin, as a public literary figure, was directly affected by this situation, and he addressed it in the poem "Saint Francis and the Poor Jews," written in 1932.

\section{4. "Saint Francis and the Poor Jews"}

What Wittlin found particularly distressing about the anti-Semitism he experienced in Poland (and what he frequently returned to in his journal) was that many of its propagators were closely associated with the Catholic Church to which he felt increasingly drawn. Indeed, Dmowski's vision of a homogenous nation-state began to appeal to a number of Catholic priests and intellectuals, especially those who considered themselves staunch anti-modernists. When the Roman Catholic authorities struggled to defuse the modernist crisis between the 1900s-1920s, the discourse of the "enemy inside" began to hold sway in the official Catholic rhetoric. By the late 1920s, however, it would not only be modernists who were accused of disguised attempts to destroy Christianity, but also freemasons, communists, and Jews - all considered destructive forces of modernity. The perceived necessity to resist the Jewish-masonic-communist conspiracy was obviously in conflict with the Christian command to love one's neighbour, which, as Brian Porter-Szücs observes, remained one of the "profound gaps" that can be identified between Polish Catholic anti-Semitism and the "secular teachings of racialist

34 N. Davies, God's Playground A History of Poland: Volume II: 1795 to the Present, Oxford-New York: Oxford University Press, 2005, p. 189.

35 Dmowski and his party never gained much official political power, but their impact on the public discourse of the time was immense. They openly endorsed an anti-Semitic agenda, arguing for the Polonisation of ethnic minorities. On Dmowski's political worldview, see A. Kossert, "Founding Father of Modern Poland and Nationalistic Antisemite: Roman Dmowski" [in:] In the Shadow of Hitler: Personalities of the Right in Central and Eastern Europe, ed. R. Haynes, M. Rady, London: I.B. Tauris, 2011, pp. 89-104. 
antisemitism" in Nazi Germany. ${ }^{36}$ It often led, Porter-Szücs adds, to serious "moments of cognitive dissonance." ${ }^{37}$ The Manichean rhetoric developed during the campaign against Catholic modernists, Porter-Szűcs contends, fit anti-Semitic discourse well. In fact, a number of thinkers across Europe who in the 1900s-1910s took a strictly anti-modernist stance, in the 1920s-1930s would in a similar way endorse anti-Semitic rhetoric. Thus, in 1921, Jacques Maritain (notwithstanding the fact that his wife Raĩssa was a Russian-born Jew) argued for the "necessity" for of Christians to "struggle for civic health against the secret judaeo-masonic societies and against cosmopolitan finance." ${ }^{38}$ Similarly, in 1933, T.S. Eliot infamously stated that "where two or more cultures exist in the same place they are likely to be fiercely self-conscious or both to become adulterate. (...) reasons of race and religion combine to make any large number of free-thinking Jews undesirable." 39 The construction of the Jew as a potentially subversive member of society who threatens its Christian character paralleled the way in which modernist theologians were portrayed in the anti-modernist texts of the previous decades.

Wittlin personally experienced the damaging effects of this discourse, as it was by no means limited to politics or religion; it pervaded the intellectual, cultural, and literary life of inter-war Poland, ruining the careers of a number of Polish-Jewish writers and artists. Dmowski argued that Jews threatened Poland not only economically, depriving hard-working Poles of employment, but also culturally, threatening to undermine what he considered Polish values. "The ranks of Poles of Jewish descent increased enormously," he wrote in 1909, "but these Poles were ever more superficial (...) with a separate spirit,

36 Porter-Szűcs observes that " $\mathrm{t}]$ here was a pattern to the anti-Semitic tirades in the Catholic press: they would begin with a vehement depiction of the Jewish menace, then proceed to a call for Poles to 'support their own,' then end by imagining an almost magical (or perhaps Providential) disappearance of the Jews. (...) At this point of logical disjuncture stood the commandment to love one's enemy. Catholics in inter-war Poland found it nearly impossible to reconcile this teaching with their desire to get rid of the Jews, and the result was a conspicuous silence when it came to discussing how this goal might be attained." Ibidem, pp. 305-306. See also, B. Porter[-Szücs], "Anti-Semitism and the Search for a Catholic Modernity" [in:] Antisemitism and Its Opponents in Modern Poland, ed. R. Blobaum, Ithaca, NY: Cornell University Press, 2005, pp. 103-123.

37 Ibidem, p. 302.

38 J. Maritain, "À propos de la question juive" [On the Jewish Question], La Vie spirituelle [The Spiritual Life] July 1921, 2 (4) quoted in R.A. Ventresca, "Jacques Maritain and the Jewish Question: Theology, Identity and Politics," Studies in Christian-Jewish Relations 2007, 2 (2), pp. 58-69 (p. 63). In the 1910s and early 1920s, Maritain was considered "the official philosopher of Action Française," a far-right nationalist movement led by Charles Maurras. After the movement was condemned by the Vatican in 1926, Maritain dissociated himself from it, and in the 1930s became a staunch opponent of anti-Semitism. See also Jacques Maritain and the Jews, ed. R. Royal, Notre Dame, IN: University of Notre Dame Press, 1994; R.F. Crane, Passion of Israel: Jacques Maritain, Catholic Conscience, and the Holocaust, Scranton, PA: University of Scranton Press, 2010.

39 T.S. Eliot, After Strange Gods, op. cit., pp. 19-20. 
a separate attitude toward life and its mysteries." ${ }^{40}$ In the 1920s and 1930s, Wittlin closely collaborated with the literary review Wiadomości Literackie (Literary News), whose editors and regular contributors included a number of assimilated Polish Jews. In the 1930s, the review came under continuous attack from both the right-wing Polish nationalists and the Zionist Jews for its promotion of socialist ideology and a universalist understanding of Polish and European culture. ${ }^{41}$ Exasperated by these attacks, Wittlin decided to leave for France in July 1939. Later, he ironically remarked that it was Polish anti-Semites who saved his life by forcing him to flee the country two months before it was invaded by the Nazi troops. ${ }^{42}$

When in the 1930s Wittlin was considering getting baptised in the Roman Catholic Church, he very consciously chose to postpone it until the current persecutions of Jews ceased. In 1940, he noted in his journal: "If I got baptised - I assure both Jews and Poles - the reason would not be to cease being a Jew." ${ }^{33}$ It is against this background that Wittlin's poetry of the 1930s1940 s has to be read. It is informed by his desperate search for a Christian ideal that would be powerful enough to defy the nationalist and exclusivist understanding of Catholicism. It was Francis of Assisi who provided Wittlin with such a model, which became particularly pronounced in "Saint Francis and the Poor Jews" (1932):

Your name is called in vain by

The rich, proud, righteous, and satiated.

Because you, if you were alive,

Would surely come to us who are beaten.

We poor, ragged Jews,

We spiritual scabies

Walking around with the yellow badge.

You would not be repulsed by us,

You, oh saint goy patriarch,

To the least among us would say: brother,

My brother in leprosy $!^{14}$

${ }^{40}$ Quoted in A. Polonsky, “'Why did they hate Tuwim Boy so much?' Jews and 'Artificial Jews' in the Literary Polemics in the Second Polish Republic" [in:] Antisemitism and Its Opponents in Modern Poland, ed. R. Blobaum, Ithaca, NY: Cornell University Press, 2005, pp. 189-209 (p. 193).

41 See M. M. Opalski, “Wiadomości Literackie: Polemics on the Jewish Question, 19241939" [in:] The Jews of Poland between Two World Wars, ed. Y. Gutman and others, Hanover, NH: Brandeis University Press, 1989, pp. 434-452.

42 J. Wittlin, "Letter to Jerzy Giedroyć, 4 April 1949," quoted in R. Zajączkowski, "Wolne usta poety: Ethos słowa Józefa Wittlina” [The Poet’s Free Lips: Józef Wittlin’s Verbal Ethics], p. 263.

43 J. Wittlin, [Diaries], vi: 1938-1940 [January 1940, p. 369].

44 J. Wittlin, "Święty Franciszek i biedni Żydzi" [Saint Francis and the Poor Jews] [in:] idem, Poezje [Poems], Warszawa: PIW, 1978 p. 111. 
The poem, whose form resembles a prayerful invocation, establishes a contrast between two groups of people: those who are in power on the one hand, and Jews on the other. The former are described by means of the attributes that evoke some of the Beatitudes (Matthew 5, 3-12). While Jesus blessed those who are "poor in spirit," "meek" and who "hunger and thirst for righteousness," the second line of the poem speaks about those who are "rich," "proud," "righteous" and "satiated." Thus, while the poem stops at this scanty characterisation, it makes it clear that the people referred to, who are presumably Christian, do not live in accordance with the Gospel ideal. The speaker, on pronouncing this judgement, reveals his association with the Jews, portrayed as "poor" and "ragged." The gap existing between the two groups - the wealthy and satisfied Christians and the pauperised and needy Jews - is not only economic.

The Jews are the ones who suffer persecutions; they are "beaten" and forced to wear "the yellow badge." Historically, the obligation to wear the yellow badge was first forced on Jews in 1215 by the Fourth Council of Lateran. ${ }^{45}$ It was designed as an identifying mark that responded to the anxiety caused by the realisation that Jews "cannot be distinguished by any difference" (Canon 68), and, unless they wear a distinguishing mark, their lack of observance of Christian festivals and holy days could scandalise Christian population. While the yellow badge was a medieval invention and was abolished by most European countries by the seventeenth century, its mention by Wittlin in 1932 proved ominously prophetic. Seven years later, when the Nazis invaded Poland, they reinstated the yellow badge, requiring all Jews to wear a Star of David badge or armband under the threat of death. ${ }^{46}$ The twentieth-century urge to construct the Jew as a separate and visibly distinct member of society, which found its fulfilment in the ideology of Nazism, was a response, as Zygmunt Bauman argues, to the "eroding power of social and legal equality and cross-cultural exchange." ${ }^{47}$ Without the badge, Jews could successfully pass for Christians and merge perfectly into modern society.

The poem calls the Jews "spiritual lepers," pointing to a connection recurrent in anti-Semitic discourse. For centuries, Jews have been accused of literally transmitting infectious diseases; in the Middle Ages, they were suspected, together with lepers, of poisoning wells. ${ }^{48}$ Since the medieval times, both

45 "The Twelfth General Council (Fourth Lateran Council, 1215)" [in:] Disciplinary Decrees of the General Councils: Text, Translation and Commentary, ed. H.J. Schroeder, St Louis: Herder, 1937, pp. 236-296 (Canon 68, pp. 290-291). See also G. Kisch, "The Yellow Badge in History," Historia Judaica 1957, 19, pp. 89-146.

46 See Ph. Friedman, "The Jewish Badge and the Yellow Star in the Nazi Era," Historia Judaica 1955, 17, pp. 41-70; S. Doran, The Culture of Yellow, or, the Visual Politics of Late Modernity, London: Bloomsbury, 2013, esp. chapter 6: "Yellow Stars and the Visual Politics of Genocide," pp. 159-188.

47 Z. Bauman, Modernity and the Holocaust, New York: Cornell University Press, 1991, p. 58.

48 For a first-century discussion of such anti-Semitic prejudices, see Josephus, "Against Apion, or on the Antiquity of the Jews" [in:] Josephus, The Life. Against Apion, with an English 
groups have been marginalised, with lepers obliged to carry bells that warned other citizens that they were approaching and frequently forced to live in leper colonies, and with Jewish communities often confined to ghettos. The poem's reference to the Jews as both "poor" and "spiritual lepers" evokes yet another beatitude: "Blessed are the poor in spirit: for theirs is the kingdom of heaven" (Matthew 5, 3). Thus, the image of Jews as "spiritual lepers" can be read both literally - Jews are like lepers because they are persecuted, despised, and excluded from society due to their spiritual otherness - and in a more religious way as the "poor in spirit" who, by virtue of their humility, stand in opposition to those who consider themselves righteous and morally superior. The speaker expresses his conviction that Francis, the "saint goy patriarch," would recognise their poverty and choose their company over that of the self-satisfied.

It is through the person of Francis that the image of the leper gains yet another dimension. It evokes a story of Francis's meeting with a leper, which eventually led to his spiritual metamorphosis and conversion to Christianity. Sabatier recounts this meeting in the following way:

He [Francis - J.R.] was riding on horseback one day, his mind more than ever possessed with the desire to lead a life of absolute devotion, when at a turn of the road he found himself face to face with a leper. The frightful malady had always inspired in him an invincible repulsion. He could not control a movement of horror, and by instinct he turned his horse in another direction.

If the shock had been severe, the defeat was complete. He reproached himself bitterly. To cherish such fine projects and show himself so cowardly! Was the knight of Christ then going to give up his arms? He retraced his steps and springing from his horse he gave to the astounded sufferer all the money that he had; then kissed his hand as he would have done to a priest. This new victory, as he himself saw, marked an era in his spiritual life. ${ }^{49}$

The passage shows Francis two years after he initially began contemplating leading a Christian life. He has gradually renounced his father's fortune, fasted, given alms, and spent time with the beggars of Assisi. And yet, Francis's meeting with the leper turns into a lesson on humility. His initial reaction to the leper - defined by fear and revulsion - shows his shock at facing a person whom he has been socialised to disregard and avoid. Thus, he approaches the leper not as his neighbour, but as a carrier of the "frightful malady." Shortly, however, comes a realisation that leprosy does not erase the leper's humanity, and objectifying him by defining him through his illness is deeply un-Christian. Francis's turning back and embracing the leper becomes literally his act of conversion

translation by H.St.J. Thackeray, Loeb Classical Library, 186, London: William Heinemann, 1961, pp. 161-411. See also G. Kisch, op. cit., pp. 97-101.

49 P. Sabatier, Life of St. Francis of Assisi, op. cit., p. 26. 
(Latin conversio can be translated as "turning around") and the moment when he accepts full Christian responsibility for his needy neighbour. Francis's meeting with the marginalised "other" results in his spiritual transformation a recognition that the Christian ideal of renunciation of worldly life cannot be divorced from an everyday praxis of charity towards others, especially those who are ignored and shunned. Thus, the speaker of Wittlin's poem expresses his conviction that in contemporary times Francis would embrace the Jews with as much charity as he embraced the leper: "You would not be repulsed by us" and "To the least among us would say: brother | Brother scab!" Echoing the Gospel pronouncement: "Verily I say unto you, Inasmuch as ye have done it unto one of the least of these my brethren, ye have done it unto me" (Matthew 25, 40), the final lines of the poem allude to Francis's custom of calling all those with whom he interacted, as well as animals and inanimate objects of creation, "brothers" and "sisters," as in his "The Canticle of Brother Sun." Francis's conversion leads him to reorient his life. He develops compassion for those who are marginalised, persecuted, and "beaten" - and distances himself from "the rich, proud, righteous, and satiated."

This active attention to others' suffering that translates into a Christian praxis is what Wittlin found particularly inspiring in Francis's life. He explored it in a number of poems written during the Polish-Ukrainian War. Francis provided him with a model for overcoming the hatred and violence perpetrated during the conflict and in the inter-war period. In the 1920s, Wittlin records in his journal that "to understand St Francis, one needs to [also be able to] stand by the side of the oppressors, and have compassion for them." ${ }^{51}$ This was precisely what Wittlin attempted to do in a number of poems he composed in this period. ${ }^{52}$ In "Do przeciwnika" (To the Adversary), he portrays a bloody battle after which two surviving soldiers look each other in the face and recognise one another's humanity. ${ }^{53}$ "Grzebanie wroga" (Burying Your Enemy) further explores the dialectic between the terms "brother" and "enemy" and the artificiality of this distinction. The speaker, charged with the task of burying

50 Known also as "The Canticle of the Creatures." See Francis of Assisi, "The Canticle of the Creatures (1225)" [in:] Francis of Assisi: Early Documents, ed. R.J. Armstrong, J.A. Wayne Hellmann, W.J. Short, trans. R.J. Armstrong and others, 3 vols, New York: New York City Press, 1999-2001, I: The Saint (1999), pp. 113-114.

51 J. Wittlin, [Diaries], I: 1920s-1932 [1920s, p. 31].

52 Apart from this, Wittlin also attempted to challenge the common perception of the enemy. For instance, in 1933 he took a firm stance against a proposed boycott of German-language books that was to be a response to the Nazis' persecutions of Poles living in Germany. In an article written in defence of German authors, Wittlin argued that anger at Hitler's violence should not be turned against writers who did nothing to facilitate Hitler's rise to power. Józef Wittlin, "W obronie książek niemieckich" [In Defence of German Books], Wiadomości Literackie [Literary News], 7 May 1933, p. 5.

53 J. Wittlin, "Do przeciwnika" [To the Adversary] [in:] idem, Poezje [Poems], op. cit., pp. 53-55. 
the enemy's corpse, gradually develops an awareness that the semantic boundary between the words "enemy" (wróg) and "brother" (brat) is fluid and artificial:

I know only this: he is an enemy.

Cause the shape of his hat is foreign and foreign are his buttons,

Though his half-closed eyes and hand, that clutches the gun

Is as much in pain

Is as much tired

As the hand of my brother, as my brother's palm. ${ }^{54}$

The poem echoes Francis's admonition "Of Love," in which he pronounces that "He truly loves his enemy who does not grieve because of the wrong done to himself, and who is afflicted for love of God because of the sin on his [brother's] soul and who shows his love by his works." 55 It is love that enables one to overcome one's prejudices and socially imposed conventions and makes it possible to see a brother or sister in those from whom one is traditionally separated by political, social, economic, or religious boundaries, and that for Wittlin shapes a truly Christian worldview. The modern-day sainthood, his poems imply, does entail acting against established conventions and accepting a universal responsibility for others, especially those more vulnerable.

In his essay "Wojna, pokój i dusza poety" (War, Peace, and the Poet's Soul, 1929), Wittlin voices his disillusionment with the way in which Christian churches allied with political propaganda and abused religious discourse to incite hatred against those who at a given moment were considered "enemies." He proposes to turn to poetry as a means of unburying the truly revolutionary message of Christianity. "Perhaps one day thanks to poetry," he writes, "if not anything else, we will become gentle and joyful, and will hurry to wash our bloody hands (...) and embrace each other." 56 In the essay "Apollon i Asklepios" (Apollo and Asclepius, 1938), he further argues that poets are especially capable of following in the footsteps of Saint Francis because, just like medical doctors, they tend to be particularly sensitive to others and their suffering:

54 Idem, "Grzebanie wroga" [Burying Your Enemy] [in:] idem, Poezje [Poems], op. cit., pp. 31-37 (p. 31, 11. 10-15).

55 Francis of Assisi, "Words of Admonition," op. cit., p. 12.

56 J. Wittlin, "Wojna, pokój i dusza poety” [War, Peace, and the Poet’s Soul], op. cit., p. 44. 
Honest poets and doctors, first and foremost, try to examine people, look into them, identify the source of suffering, and name what they have found. Then they try to describe the changes they have observed in the human body and soul. ${ }^{57}$

While the task of medicine is to alleviate suffering, the social but also the religious mission of poetry, Wittlin observes, is to describe it - to give voice to those who otherwise might not be heard because they have been silenced by the political or religious discourse of the time.

\section{Bibliography}

Bauman Z., Modernity and the Holocaust, New York: Cornell University Press, 1991. Catholicism Contending with Modernity: Roman Catholic Modernism and Anti-Modernism in Historical Context, ed. D. Jodock, Cambridge: Cambridge University Press, 2000.

Chesterton G.K., Saint Francis of Assisi, London: Hodder and Stoughton, 1923. Crane R.F., Passion of Israel: Jacques Maritain, Catholic Conscience, and the Holocaust, Scranton, PA: University of Scranton Press, 2010.

Cudak R., “'Otom przed Tobą, Abraham': Lektura wiersza Józefa Wittlina 'Trwoga przed śmiercią" ["I, Abraham, Stand before You": A Reading of the Poem "Fear of Death" by Józef Wittlin] [in:] Studia o twórczości Józefa Wittlina [Studies on the Writings of Józef Wittlin], ed. I. Opacki, Katowice: Uniwersytet Śląski, 1990.

Davies N., God's Playground A History of Poland: Volume II: 1795 to the Present, Oxford-New York: Oxford University Press, 2005.

Delehaye H., The Legends of the Saints: An Introduction to Hagiography, trans. V.M. Crawford, London: Longmans, Green, and Co., 1907.

Delehaye H., Work of the Bollandists through Three Centuries, 1615-1915, Princeton: Princeton University Press, 1922.

Disciplinary Decrees of the General Councils: Text, Translation and Commentary, ed. H.J. Schroeder, St Louis: Herder, 1937.

Doran S., The Culture of Yellow, or, the Visual Politics of Late Modernity, London: Bloomsbury, 2013.

Eliot T.S., After Strange Gods, London: Faber \& Faber, 1934.

Faure G., Pèlerinages d'Italie: au pays de Saint François d'Assise et de Sainte Catherine de Sienne, Paris: Perrin, 1920.

Francis of Assisi: Early Documents, ed. R.J. Armstrong, J.A.W. Hellmann, W.J. Short, trans. R.J. Armstrong and others, 3 vols, New York: New York City Press, 1999-2001.

57 Idem, "Apollon i Asklepios" [Apollo and Asclepius] [in:] idem, Orfeusz w piekle XX wie$k u$ [Orpheus in the Inferno of the Twentieth Century], pp. 528-534 (p. 530) (first publ. in Medycyna i przyroda [Medicine and Nature] 1938, 1, pp. 31-34). 
Friedman Ph., "The Jewish Badge and the Yellow Star in the Nazi Era," Historia Judaica 1955, 17.

Gwynn A., "The Bollandists: Past and Present," Studies: An Irish Quarterly Review 1946, vol. 35, no. 137.

Hagen W.W., "The Moral Economy of Popular Violence: The Pogrom in Lwów, November 1918" [in:] Antisemitism and Its Opponents in Modern Poland, ed. R. Blobaum, Ithaca, NY: Cornell University Press, 2005.

Jacques Maritain and the Jews, ed. R. Royal, Notre Dame, IN: University of Notre Dame Press, 1994.

Jenkins P., The Great and Holy War: How World War I Became a Religious Crusade, New York: HarperOne, 2014.

Josephus, "Against Apion, or on the Antiquity of the Jews" [in:] Josephus, The Life. Against Apion, with an English translation H.St.J. Thackeray, Loeb Classical Library, 186, London: William Heinemann, 1961.

Kisch G., "The Yellow Badge in History," Historia Judaica 1957, 19.

Kosakowska E., "The War as a Myth: The Analysis of a Development of the Religious Imagery in Joseph Wittlin's The Salt of the Earth" [in:] Between Lvov, New York, and Ulysses' Ithaca: Józef Wittlin: Poet, Essayist, Novelist, ed. A. Frajlich, Toruń: Nicholas Copernicus University, 2001.

Kossert A., "Founding Father of Modern Poland and Nationalistic Antisemite: Roman Dmowski" [in:] In the Shadow of Hitler: Personalities of the Right in Central and Eastern Europe, ed. R. Haynes, M. Rady, London: I.B. Tauris, 2011. Little A.G., "The Seventh Centenary of St. Francis of Assisi (1226-1926)" [in:] Franciscan Essays II, ed. F.C. Burkitt, H.E. Goad, A.G. Little, Manchester: University Press, 1932.

Maritain J., "À propos de la question juive" [On the Jewish Question], La Vie spirituelle [The Spiritual Life], July 1921, 2 (4).

Opalski M. M., "Wiadomości Literackie: Polemics on the Jewish Question, 19241939" [in:] The Jews of Poland between Two World Wars, ed. Y. Gutman and others, Hanover, NH: Brandeis University Press, 1989.

Peters U., Franz von Assisi, Tübingen: Mohr, 1912.

Polonsky A., "'Why did they hate Tuwim Boy so much?' Jews and 'Artificial Jews' in the Literary Polemics in the Second Polish Republic" [in:] ed. R. Blobaum, Ithaca, NY: Cornell University Press, 2005.

Porter[-Szücs] B., "Anti-Semitism and the Search for a Catholic Modernity" [in:] Antisemitism and Its Opponents in Modern Poland, ed. R. Blobaum, Ithaca, NY: Cornell University Press, 2005.

Sabatier P., Vie de saint François d'Assise, Paris: Libraire Fischbacher, 1893 (in English as Life of St. Francis of Assisi, trans. L.S. Houghton, London: Hodder and Stoughton, 1894; in German as Das Leben des heiligen Franz von Assisi, trans. M. Lisco, Berlin: De Gruyter, 1895).

Saitschick R., Franziskus von Assisi, München: C.H. Beck, 1917.

Schultenover D.G., A View from Rome: On the Eve of the Modernist Crisis, New York: Fordham University Press, 1993. 
Sokolow N., "Henri Bergson's Old-Warsaw Lineage" [in:] L.S. Dawidowicz, The Golden Tradition: Jewish Life and Thought in Eastern Europe, Syracuse, NY: Syracuse University Press, 1996.

Talar C.J.T., "Discourse on Method: Hippolyte Delehaye's Légendes hagiographiques" [in:] Medieval Saints in Late Nineteenth Century French Culture: Eight Essays, ed. E. Emery, L. Postlewate, Jefferson, NC: McFarland \& Co., 2004.

Talar C.J.T., "Saint of Authority and the Saint of the Spirit: Paul Sabatier's Vie de saint François d'Assise" [in:] Sanctity and Secularity during the Modernist Period: Six Perspectives on Hagiography Around 1900, ed. L.F. Barmann, C.J.T. Talar, Brussels: Société des Bollandistes, 1999.

Thomas of Celano, The Life of Saint Francis.

U.S. Catholic Historian, 2007, 25(1): Pascendi dominici gregis 1907-2007: Centennial Essays on Responses to the Encyclical on Modernism.

Van der Wall, E., The Enemy Within: Religion, Science, and Modernism, Wassenaar: NIAS, 2007.

Vauchez A., Francis of Assisi: The Life and Afterlife of a Medieval Saint, trans. M.F. Cusato, New Haven: Yale University Press, 2012.

Ventresca R.A., "Jacques Maritain and the Jewish Question: Theology, Identity and Politics," Studies in Christian-Jewish Relations 2007, 2 (2).

Williams B., The Franciscan Revival in the Anglican Communion, London: Darton, Longman and Todd, 1982.

Wittlin J., [Diaries], 12 vols, unpublished.

Wittlin J., Listy [Letters], ed. T. Januszewski, Warszawa: Niezależna Oficyna Wydawnicza, 1996.

Wittlin J., Orfeusz w piekle XX wieku [Orpheus in the Inferno of the Twentieth Century], Kraków: Wydawnictwo Literackie, 2000.

Wittlin J., Pisma pośmiertne i inne eseje [Posthumous Writings and Other Essays], ed. J. Zieliński, Warszawa: Biblioteka Więzi, 1991.

Wittlin J., Poezje [Poems], Warszawa: PIW, 1978.

Wittlin J., Swięty Franciszek z Asyżu [Saint Francis of Assisi], Warszawa: Biblioteka Więzi, 1997.

Wittlin J., "W obronie książek niemieckich" [In Defence of German Books], Wiadomości Literackie [Literary News], 7 May 1933.

Yurieff Z., Joseph Wittlin, New York: Twayne Publishers, 1973.

Zajączkowski R., "Korespondencja między Józefem Wittlinem i Romanem Brandstaetterem" [Correspondence between Józef Wittlin and Roman Brandstaetter], Tematy i Konteksty, 2012, 2(7).

Zajączkowski R., "Wolne usta poety: Ethos słowa Józefa Wittlina” [The Poet's Free Lips: Józef Wittlin's Verbal Ethics], Ethos [Ethos] 2012, 97/98. 